\title{
THE ROLE OF ISLAMIC EDUCATION TEACHERS IN PREVENTING RADICALISM AT MADRASA ALIYAH
}

\author{
Udin Supriadi', Usup Romli², Mohammad Rindu Fajar Islamy ${ }^{3}$, Muhamad Parhan ${ }^{4}$, \\ Nurti Budiyanti ${ }^{5}$ \\ Universitas Pendidikan Indonesia, Indonesia ${ }^{1,2,3,4,5}$ \\ udinsupriadi@upi.edu, usupromli@upi.edu,fajarislam2000@upi.edu, \\ parhan.muhamad@upi.edu, nurtibudiyanti@upi.edu.
}
Received: 11-09-2020
Revised: 24-01-2021
Accepted: 18-02-2021

\begin{abstract}
Radicalism is seen as dangerous for the integrity of the Republic of Indonesia. It is contradictory to Islamic values, where Islam upholds the principles of tolerance, peace, and respect for one's beliefs. Therefore, serious efforts are required from all levels of society to minimize the spread of this understanding, especially for the millennial generation. This study aims to find conceptual ideal ideas to deal with issues of radicalism through the role of (IRE) Islamic Religious Education teachers in the formal learning process at schools. This study employed a qualitative approach with a descriptive analysis method. The study was carried out in Madrasa Aliyah (Islamic Senior High School) Maarif Tanjung Sari Sumedang. Data were collected through an interview, observation, and discussion. The data were analyzed using the interactive analysis technique. Results of the study revealed that the Islamic Religious Education teacher of MA Maarif Tanjung Sari played an important role in stemming radicalism. Implementing 5 principles in the teaching-learning process is the key.
\end{abstract}

Keywords: Teacher, Islamic Religious Education (IRE), Radicalism, Madrasa

\begin{abstract}
Abstrak
Paham radikalisme dipandang berbahaya bagi keutuban Negara Kesatuan Republik Indonesia. Paham ini kontradiktif dengan nilai-nilai ajaran Islam, dimana Islam menjunjung tinggi prinsipprinsip toleransi, perdamaian, maupun prinsip menghargai keyakinan seseorang. Oleb sebab itu, diperlukan upaya-upaya serius dari selurub lapisan masyarakat untuk meminimalisir beredarnya wabah paham ini terutama bagi generasi millenial. Penelitian ini bertujuan untuk menemukan gagasan konseptual ideal dalam rangka menangani isu-isu radikalisme melalui peran guru Pendidikan Agama Islam dalam proses pembelajaran formal di sekolah. Penelitian ini menggunakan pendekatan kualitatif dengan metode deskriptif analisis. Penelitian ini dilakukan di Madrasah Aliyah Ma'arif Tanjung Sari Sumedang. Data di kumpulkan melalui wawancara, observasi, dan diskusi. Data tersebut kemudian dianalisa menggunakan analisis interaktif. Hasil penelitian menemukan hasil bahwa guru Pendidikan Agama Islam MA Maarif Tanjung Sari berperan penting dalam membendung raham radikalisme. Penerapkan 5 prinsip dalam proses pembelajaran adalah kunci utama.
\end{abstract}

Kata Kunci: Guru, Pendidikan Agama Islam, Radikalisme Madrasah 


\section{INTRODUCTION}

Salafi Jihadi Group, who are known for its radicalism and extreme movement, became popular among the global community in the early $1980 \mathrm{~s}^{1}$. The emergence of this group is a response to the deep tyranny of the rulers towards their people, especially Muslims throughout the world. The political Islamization project echoed by the Salafi Jihadi Group is a campaign in their efforts to restore Islamic shari'a which is seen as being started to fade and reduced due to the trend of globalization and modernization. ${ }^{2}$ Kepel sees that the flow of extremism brought by the group with the style of a hard $d a^{\prime} w a$ movement without discrimination is alleged to have connections and relationships with several world institutions in funding assistance to make the programs into realization ${ }^{3}$. Among the donors who consistently and routinely give funds are Government of Saudi Arabia, which is held by Muassasah al-Haramain al-Khairiyya and Rabithah al-Alam al-Islami and Kuwaiti government, which is regulated and managed by the Kuwaiti Jam'iyyat Ibya At-Thurath al-Islami agency ${ }^{4}$. They put efforts to create a sectarian ideology that suits what they want. However, it seems that this global project is not going as smoothly as they thought. Various efforts have been made by state leaders in various parts of the world to stem these ideologies. Through the use of military and army power, the leaders could make pressure to these radical movements so that the extrimists were somewhat stagnated and were not free to penetrate areas which were considered as potential to apply their purposes ${ }^{5}$.

In the beginning of the 21 st century, the Islamic world was shocked by the World Trade Center (WTC) bombing that occurred in September 11, 2001. Various views emerged from Muslim scholars in response to the tragedy. Many considered that United States government was involved through a conspiracy to impose the global view of the Islamic religion. Many observers believed that the global war on terror was a war against Islam based on an analysis of the clash of civilizations ${ }^{6}$. In short, the emergence of radicalism and other similar movements which were related to global issues deemed as the clash of civilizations and

${ }^{1}$ Muhammad Sani Umar and Mark Woodward, “The Izala Effect: Unintended Consequences of Salafi Radicalism in Indonesia and Nigeria," Contemporary Islam 14, no. 1 (April 2020): 49-73, https://doi.org/10.1007/s11562-019-00441-y.

2G. Kepel, "Jihad: The Trial of Political Islam” (Harvard University Press, 2002).

${ }^{3}$ Abdallah Abdallah, "Exclusivism and Radicalism in Schools: State Policy and Educational Politics Revisited," Studia Islamika 23, no. 3 (December 30, 2016): 625-32, https://doi.org/10.15408/sdi.v23i3.4425; Alexander R Arifianto, "Islamic Campus Preaching Organizations in Indonesia: Promoters of Moderation or Radicalism?," Asian Security 15, no. 3 (September 2, 2019): 323-42, https://doi.org/10.1080/14799855.2018.1461086.

${ }^{4}$ Umar and Woodward, "The Izala Effect: Unintended Consequences of Salafi Radicalism in Indonesia and Nigeria."

${ }^{5}$ Choirul Mahfud et al., "Religious Radicalism, Global Terrorism and Islamic Challenges in Contemporary Indonesia," Jurnal Sosial Humaniora 11, no. 1 (July 27, 2018): 8-18-18, https://doi.org/10.12962/j24433527.v11i1.3550; Zakiyuddin Baidhawy, "The Muhammadiyah's Promotion of Moderation," American Journal of Islamic Social Sciences 32, no. 3 (2015): 69-91; Nuraan Davids, "Islam, Moderation, Radicalism, and Justly Balanced Communities," Journal of Muslim Minority Affairs 37, no. 3 (July 3, 2017): 309-20, https://doi.org/10.1080/13602004.2017.1384672.

${ }^{6}$ Ahmad Fuad Fanani, "The Global War on Terror, American Foreign Policy, and Its Impact on Islam and Muslim Societies," Indonesian Journal of Islam and Muslim Societies 1, no. 2 (2011): 205-27, https://doi.org/10.18326/ijims.v1i2.205-255. 
religious ideology. Al-Qaeda, which was led by Osama bin Laden, was a form of protest against the rampant Munkar that has occurred in several regions of Muslim countries.

In Indonesia, Islam is seen as a religion that is in harmony with traditions and culture of Indonesian people where they uphold the values of peace, tolerance, respect among religious adherents so that the values can minimize clashes between communities caused by religious ideological conflicts ${ }^{7}$. Nevertheless, issues of radicalism movement in Indonesia have gained popularity in connection with the number of news related to groups acting on behalf of alQaeda and ISIS. Some view that this group was trying to fight the rampant injustice but they did it in the wrong ways and steps. Some also view that the outbreak of the radicalism movement in Indonesia was caused by changes in the social and political order which were influenced by the presence of immigrants from Arab and Yemeni Hadramaut. The immigrants transferred their ideology, including Wahabbi ideology which was initiated by Muhammad bin Abdul Wahab, to Indonesian society. The ideology was in fact adopted by some Indonesian gradually. Hence, the movement that emerged in Arabia began to gradually move to Indonesia.

Indonesia's history records that post-independence and post-reformation was seen as a period of strengthening the history of Islamic radicalism. The Kartosuwirjo Movement in the 1950s, called as Daarul Islam (DI), was a political movement that had an agenda to restore Islamic sharia and implemented it nationally in Indonesia ${ }^{8}$. This understanding received strong resistance from both government agencies and great scholars so that in the end it was thwarted. This movement reappeared during the Soeharto's presidency with a different style and nuance. This radical movement emerged due to military engineering or through intelligence held by Ali Moertopo with his special operations. There were Bakin, who tried to persuade members of the DI/TII group and ordered to carry out various actions, and Komando Jihad, who had a duty to corner Islam. Komando Jihad (KOMJI) emerged in 1976 and carried out an extreme movement by blowing up places of worship. In 1977, the Indonesian Muslim Liberation Front did the same. There were also acts of terror carried out by the Islamic Revolutionary Struggle Pattern in $1978^{9}$. Then after the post-reform era, namely the fall of President Soeharto in 1998, terrorist movements initiated by Azhari and Nurdin M. Top emerged to impose a reformist Islamic ideology aimed at enforcing Islamic sharia in their forms and methods ${ }^{10}$. The idea of this group is a false response to their paradigm of thinking

${ }^{7}$ Ahmad Asrori, "RADIKALISME DI INDONESIA: Antara Historisitas Dan Antropisitas," Kalam 9, no. 2 (2017): 253, https://doi.org/10.24042/klm.v9i2.331.

8Marzuki Marzuki, Miftahuddin Miftahuddin, and Mukhamad Murdiono, "Multicultural Education in Salaf Pesantren and Prevention of Religious Radicalism in Indonesia," Jurnal Cakrawala Pendidikan 39, no. 1 (February 2, 2020): 12-25, https://doi.org/10.21831/cp.v39i1.22900; Wahid Khozin, "Sikap Keagamaan Dan Potensi Radikalisme Agama Mahasiswa Perguruan Tinggi Agama," EDUKASI: Jurnal Penelitian Pendidikan Agama dan Keagamaan 11, no. 3 (December 1, 2013), https://doi.org/10.32729/edukasi.v11i3.415.

'Ari Kartiko et al., "Aswaja Ke-Nuan-Based Islamic Moderate Education as a Radicalism Strategy," AlAfkear, Journal For Islamic Studies 3, no. 2 (October 8, 2020): 88-101, https://doi.org/10.31943/afkar_journal.v3i2.98.

${ }^{10}$ Ahmad Asrori, "Radikalisme Di Indonesia: Antara Historisitas Dan Antropisitas," KALAM 9, no. 2 (December 30, 2015): 253-68, https://doi.org/10.24042/klm.v9i2.331; Achmad Asrori, “Contemporary Religious Education Model on the Challenge of Indonesian Multiculturalism," JOURNAL OF INDONESLAN ISLAM 10, no. 2 (December 1, 2016): 261-84, https://doi.org/10.15642/JIIS.2016.10.2.261-284. 
that Indonesia is a country that does not uphold Islamic sharia, this paradigm is eventually straightened out by the Indonesian archipelago ulama.

Ulama from various regions around the world tries to try to extract the essence of the contents of the Koran to prevent the emergence of radical practices that contradict the values of Islami. Yūsuf al-Qardhāwi, in one of his works, explains the dangers of radicalism. According to him, radicalism begins with a wrong view of the concept of Islam, where extremism in doing something is strictly prohibited, even in terms of worship. According to him, Islam teaches balances in various aspects and does not neglect one aspect to pursue another one. This is also in line with the principles actualized by Rasulullah in his daily life. Rasulullah saw said in one hadith:

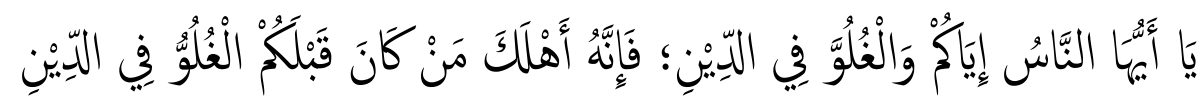

"O people, stay away from exaggeration in religion because actually what destroys the people before you are an exaggeration in religion." (Narrated by Ibn Majah)

In another narration, Rasulullah saw said:

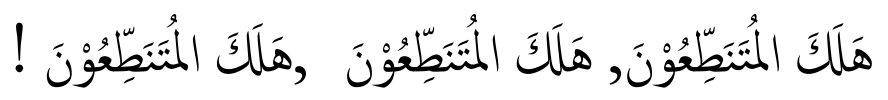

"Surely those who are superfluous in religion will perish." (HR Muslim)

From some of the Hadith narrations above, Islam views that extremism both in terms of ideology and in the form of a practical level will bring about destruction for those who apply it. ${ }^{11}$. This of course can be dangerous, especially if it is decorated and mixed with the slander of takfiri, that is the slander who likes to infidel fellow Muslims. The impact of this ideology is that it always blames others who are not in line with their ideology so that it is even more fatal when expressed in the form of brutal acts, and the damage will not only affect themselves but also Muslims as the whole.

Radicalism is a dangerous understanding for the integrity of the Unitary State of the Republic of Indonesia. Extreme movements that are not in harmony with the Indonesian culture will create new conflicts and problems that can have a fatal impact on Indonesian society either directly or indirectly. Radical actions such as terror and suicide bombings will cause foreign tourists a fright to come to Indonesia so that of course it will directly affect the national economy. The decline in income will also create a widening poverty gap so that there will be an increase in the unemployment rate in various parts of Indonesia.

\section{LITERATURE REVIEW}

Various studies have been carried out by intellectuals, both Muslim and non-Muslim, on the issue of radicalism from the classical to modern phases. Islamic Radicalism on Southeast Asia is a research that focuses on studies related to issues of radicalism in Southeast Asia, as well as the suspicion of the involvement of several Islamic reformist movements in mobilizing radicalism, this is confirmed by the Bali bomb explosion which is strongly suspected of the

\footnotetext{
${ }^{11}$ Yusuf Al-Qardhawi, Dzāhiratu Al-Gulumwn Fì At-Takfìr (Mesir Kairo: Cairo: Maktabah Wahbah, 1990).
} 
involvement of Jama'ah Islamiyyah in the behind of the incident ${ }^{12}$. The Scientists throw various theories in interpreting the phenomenon of radicalism, including the theory that explains that the radicalism movement is growing rapidly due to religious resistance to the incessant trend of global modernization ${ }^{13}$. Furthermore, the research conducted by Fadlan et al entitled "Islam, Radicals, Democracy, and Global Trends in Southeast Asia", this article discusses the discourse of Islam, the radicalism movement, and its relation to the issue of democracy in Southeast Asia ${ }^{14}$. There is also a scientific paper entitled "Policies of radicalization as anti- and counter-cult ideologies"15. This study found a strong suspicion that radicalism would develop more when it is supported by culturing someone who is considered a straight-line intellectual. Kühle explored the position of the ulama to neutralize the complex understandings that are so dynamic between radical groups and counter-jihad. Kühle also provided a strategy to suppress radicalization by developing the concept of deradicalization which was adopted from various literatures. Research conducted by Kühle took the object of his research in Denmark. He observed the phenomena that were developed there in relation to the discourse of radicalism.

From the various existing literature, if grouped according to the study, then there are studies conducted by international authors and some by Indonesia researchers. Among the scientific works carried out by researchers from abroad are Brothers in arms: How Palestinian Maoists turned Jihadists ${ }^{16}$, Al-Qaeda: The true story of radical Islam ${ }^{17}$, The role of Muslim identity politics in radicalization ${ }^{18}$, A Perverted Balance: Modern Salafism between Reform and Jihād ${ }^{19}$, Being a young British Iraqi Shii in London: exploring diasporic cultural and religious identityes between Britain and $\operatorname{Iraq}^{20}$, Bringing it home: Community-based approaches to counter-terrorism ${ }^{21}$, When students turn to terror: Terrorist and extremist activity on British campuses ${ }^{22}$, Towards "Policed Multiculturalism"? Counter-radicalization in

${ }^{12}$ Mahfud et al., "Religious Radicalism, Global Terrorism and Islamic Challenges in Contemporary Indonesia"; Davids, "Islam, Moderation, Radicalism, and Justly Balanced Communities"; Tiyas Nur Haryani et al., "Islamic Education in Supporting De-Radicalization: A Review of Islamic Education in Pondok Pesantren," Nadwa 12, no. 2 (January 7, 2019): 259-72, https://doi.org/10.21580/nw.2018.12.2.2581.

${ }^{13}$ Akh Muzakki, "Islamic Radicalism in Southeast Asia: With Special Reference to the Alleged Terrorist Organization, Jamā'ah Islāmiyah," Al-Jamiah: Journal of Islamic Studies 42, no. 1 (2008): 61-87, https://doi.org/10.14421/ajis.2004.421.61-87.

${ }^{14}$ Muhammad Nida' Fadlan and Rangga Eka Saputra, "Islam, Radicalism, Democracy, and Global Trends in Southeast Asia," Studia Islamika 24, no. 3 (2017): 643-47, https://doi.org/10.15408/sdi.v24i3.6566.

${ }^{15}$ Lene Kühle, "Policies of Radicalisation as Anti- A Nd Countercult Ideologies," Journal of Muslims in Europe 7, no. 2 (June 2018): 211-36, https://doi.org/10.1163/22117954-12341367.

${ }^{16}$ Manfred Sing, "Brothers in Arms: How Palestinian Maoists Turned Jihadists," Welt Des Islams (Brill, February 2011), https://doi.org/10.1163/157006011X556111.

17J. Burke, “Al-Qaeda: The True Story of Radical Islam” (Penguin, 2004).

${ }^{18} \mathrm{~T}$. Choudhury, "The Role of Muslim Identity Politics in Radicalisation (a Study in Progress)" (Department for Communities and Local Government, 2007).

${ }^{19}$ Itzchak Weismann, “A Perverted Balance: Modern Salafism between Reform and Jihād*," Die Welt Des Islams 57, no. 1 (March 2017): 33-66, https://doi.org/10.1163/15700607-00571p04.

${ }^{20}$ Zahra Ali, "Being a Young British Iraqi Shii in London: Exploring Diasporic Cultural and Religious Identities between Britain and Iraq," Contemporary Islam 13, no. 3 (2019): 349-67, https://doi.org/10.1007/s11562-018-0433-y.

${ }^{21}$ R. Briggs, C. Fieschi, and H. Lownsbrough, "Bringing It Home: Community-Based Approaches to Counter-Terrorism" (DEMOS, 2006).

22A. Glees and C. Pope, "When Students Turn to Terror: Terrorist and Extremist Activity on British Campuses" (Social Affairs Unit, 2005). 
France, the Netherlands and the United Kingdom ${ }^{23}$, and so forth. The research studies above at least the issue of radicalism are of great concern to international intellectuals in finding alternative solutions in reducing or even suppressing the rate of development of radicalism movements in various regions of the world. It seems that the radical epidemic is not only developing in Indonesia, but from the study above, it seems that this virus has already reached several developed countries, such as France, the Netherlands, England, and so on.

There are scientific studies conducted by Indonesian Muslim scholars related to the discourse of radicalism, terrorism, and related issues including Radicalism, Liberalism and Terrorism: Their Effects on Islam ${ }^{24}$, A tale of two royal cities: The narratives of Islamists' intolerance in Yogyakarta and Solo ${ }^{25}$, The global war on terror, American foreign policy, and its impact on Islam and Muslim societies ${ }^{26}$, Islam, radicalism, democracy, and global trends in southeast Asia ${ }^{27}$, Islamic Radicalism in Southeast Asia: With Special Reference to the Alleged Terrorist Organization, Jamā'ah Islāmiyah ${ }^{28}$,Modernisme dan Radikalisme Islam di Indonesia: Menafsirkan Warisan Muhammad 'Abduh dan Rashīd Riḍā ${ }^{29}$, Islamic religious education and radicalism in Indonesia: Strategy of de-radicalization through strengthening the living values education ${ }^{30}$, Radikalisme di Indonesia: Antara Historisitas dan Antropisitas ${ }^{31}$, Conflict, Jihad, and Religious Identity in Maluku, Eastern Indonesia ${ }^{32}$, and so far.Muslim intellectuals in Indonesia have participated in conducting intensive studies of popular radicalism movements in line with the outbreak of extremism, such as bombings and suicide bombings. According to the author, the above research studies can be made to a strong conclusion that at least several factors cause radical understanding. The main component is inseparable from religious issues which are sometimes politicized by groups who are not responsible for recruiting Muslim youths with lay minds so that they are indoctrinated with wrong understanding and in the end are used as tools as the main bullets in launching actions. -the action. Many scientists also suspect the involvement of extreme Islamic groups in the increase of radical actions, although this opinion must of course be scientifically proven its accuracy.

According to Ibn Qoyyim al-Jauziyyah, there are at least four dimensions in preventing or radicalism: first, stay away from sinful deeds and multiply good deeds; second, get rid of evil

${ }^{23}$ Francesco Ragazzi, “Du Ceri,” n.d.

${ }^{24}$ A Faiz Yunus, "Radikalisme, Liberalisme Dan Terorisme: Pengaruhnya Terhadap Agama Islam," Jurnal Online Studi Al-Qur An 13, no. 1 (2017): 76-94, https://doi.org/10.21009/jsq.013.1.06.

${ }^{25}$ Muhammad Najib Azca, Hakimul Ikhwan, and Moh Zaki Arrobi, "A Tale of Two Royal Cities: The Narratives of Islamists' Intolerance in Yogyakarta and Solo," Al-Jami'ah 57, no. 1 (2019): 25-50, https://doi.org/10.14421/ajis.2019.571.25-50.

${ }^{26}$ Fanani, "The Global War on Terror, American Foreign Policy, and Its Impact on Islam and Muslim Societies."

${ }^{27}$ Fadlan and Saputra, "Islam, Radicalism, Democracy, and Global Trends in Southeast Asia."

${ }^{28}$ Muzakki, "Islamic Radicalism in Southeast Asia: With Special Reference to the Alleged Terrorist Organization, Jamā’ah Islāmiyah.”

${ }^{29}$ Jajang Jahroni, "Modernisme Dan Radikalisme Islam Di Indonesia: Menafsirkan Warisan Muhammad 'Abduh Dan Rashīd Rị̣ā," Studia Islamika, 2004, https://doi.org/10.15408/sdi.v11i3.599.

${ }^{30}$ Syamsul Arifin, "Islamic Religious Education and Radicalism in Indonesia: Strategy of de-Radicalization through Strengthening the Living Values Education," Indonesian Journal of Islam and Muslim Societies 6, no. 1 (2016): 93-126, https://doi.org/10.18326/ijims.v6i1.93-126.

${ }^{31}$ Asrori, "RADIKALISME DI INDONESIA: Antara Historisitas Dan Antropisitas."

${ }^{32}$ Badrus Sholeh, "Conflict, Jihad, and Religious Identity in Maluku, Eastern Indonesia," Al-Jami'ab: Journal of Islamic Studies 46, no. 1 (2008): 71-99, https://doi.org/10.14421/ajis.2008.461.71-99. 
by reducing it, although not eliminating it completelyget rid of sins gradually by reducing them even though not to the point of eliminating them; third, eliminating sins by giving rise to similar sins; fourth, fourth, get rid of sins by committing sins that are greater than them.

The concept of Islamic religious education in stemming the flow of radicalism offered by Arifin 2019 is through the concept of LVE (Living Value Education) with the formation of student character who instills universal values, namely tolerance and empathy. According to him, inter-religious life can be established in bonds of affection, mutual respect, dignified tolerance, avoiding coercion, willingness to cooperate, not being arrogant or humble, promoting unity in differences that are carried out consistently in an educational environment.

Indonesian scholars see that one of the best solutions to prevent the rise of radical movements is to internalize the values of Islamic teachings contained in the Al-Quran and Hadith. A correct and complete understanding of the interpretation of the two sources of Islamic law, at least according to Syeikh Mustafa Al-Adawi in his work Mafatih Al-Fiqh Fi AdDin, can keep one's understanding away from extremism and radicalism. By bringing the millennial generation closer to the Koran, at least it can reduce the influence of negative influences in itself to become demands for a clear life guideline

Of all literature reviewed, no single study has explored the role of Islamic Religious Education (IRE) teachers, especially in Madrasah Aliyah (Senior High School) Maarif Tanjung Sari Sumedang to negotiate various efforts to stem radicalism which is being forced and popularized by certain individuals.

\section{RESEARCH METHODS}

The research setting in this study was Madrasah Aliyah (MA) Maarif which is located in Jln Nusa Indah No.03, Tanjungsari District the village of Tanjung Sari, Sumedang Regency. It is an educational institution that carries the vision of realizing students with good character who excel in persuasion and are ready to compete others. This institution focuses on educating its students so that they can become the foremost generations in the principles of benefiting country, religion, and society which are supported by values of religiosity based on religious teachings and intellectuality built from a good scientific learning process. The Research Subjects on this occasion, the authors tried to interact with the teachers to dig up some of the information needed to be related to the research raised through interview techniques, discussions, and interactive analysis of the information provided. The presence of students and digging deeper into the learning process related to the theme of preventing radicalism is seen as valuable data in synthesizing the formulation of the Institute in a practical effort embedded in the educational process. In data collection techniques, two main things affect the quality of research data, namely the quality of research instruments and the quality of data collection. While the quality of research instruments relates to the validity and reliability of the instruments, the quality of data collection deals with the methods used to collect data. When viewed from the data source, data collection can use primary and secondary sources. Furthermore, when viewed in terms of data collection methods or techniques, data collection techniques can be carried out by interviewing, questionnaire, observation, and a combination of the three. 
The results can be divided into two data sources: 1) primary sources, that is data sources that directly provide data for data collection, and 2) secondary sources, that is sources that do not directly provide data for data collection, for example through other people or documents. Several data collection techniques are divided into 3 techniques: 1) interview, a data collection technique used if the researcher wants to conduct a preliminary study to find problems that must be researched, and also if the researcher wants to know things from the respondents that are more in-depth and the number of respondents is small/small, 2) questionnaire, a data collection technique that is done by giving a set of questions or written statements to the respondent to answer. Besides, a questionnaire is also suitable if the number of respondents is large enough and spread over a large area, and 3) observation, a data collection technique which has specific characteristics when compared to other techniques such as interviews and questionnaires. Observation is a complex process, a process composed of various biological and psychological processes. Data collection techniques that researchers will do are observation and interview techniques. According to Darmadi, interview is a means of rechecking or proving information or information previously obtained. The reason the researcher uses the interview technique is that this technique is very appropriate for extracting information from informants.

According to Patton, data analysis is the process of arranging the sequence of data, organizing it into a pattern, category, and a basic description so that themes can be found and hypotheses can be formulated as suggested by the data. Several stages of Miles and Herberman's interactive analysis model go through four stages, namely data collection, data reduction, data presentation, and conclusion drawing.

\section{RESULTS AND DISCUSSION}

\section{Research result}

Islamic religious education teachers have a very important role in overcoming radicalism in schools, even though the implementation involves all school parties. In addition to cooperation with the school, it also works with parents/guardians of students to jointly supervise, direct, foster, and guide their children when they are at home or outside of school. There is an effort made in dealing with radicalism at MA MAARIF Tanjungsari, Sumedang. The efforts made were when they were at the time of learning and teaching.

There are two main efforts made by Islamic Religious Education teachers in teaching and learning activities to overcome Islamic radicalism. First, prior to starting teaching and learning activity, students sing Indonesia Raya and Hubbul Wathan. Second, during the teaching and learning process, the students need to: 1) respect the others. The Islamic Religious Education teacher urges students to always respect the rights and obligations of others so that division does not occur. 2) be moderate. The teacher instills in students to keep away from radical and extreme irrational views and actions. 3) respect for Creator. Islamic Religious Education Teacher always reminds students to remember Allah SWT, be grateful for all its gifts, carry out all orders, and stay away from all prohibitions.4) keep tolerance. This is the most important thing to instill in students where most of radicalism cases that arise are motivated by differences in beliefs with radical actors. 5) be fair. The teacher instructs students to behave fairly, avoid class favoritism and fanaticism, and respect for differences among Muslims. 
Islamic Religious Education (IRE) teachers have a strategic position to provide religious understanding to students. What the IRE teacher said would be a reference for students in worship and also in social interaction with other people. This shows how big the role of the IRE teacher has for students. This above gives a signal to us that Islamic Education teachers determine which direction students will go, whether they are brought by the practice of radicalism or otherwise, they can be avoided because IRE teachers carry out their roles well. Concerning islamic education teachers at MA Maarif, the following are their comments on the phenomenon of radicalism, both that occurs in the school environment and during social life.

According to researchers, radicalism occurs because of the influence of gadgets, the internet, etc. Today technology has indeed developed rapidly, but Indonesian society are still in transition, so it is easy to be influenced by negative values including radicalism. Even though radicalism is bad behavior, young people are still easily affected by negative things. They do not have firm thoughts. Besides, they are usually still very passionate about their ambitions, sometimes they are still good at it and cannot discern good and wrong behavior.The foregoing illustrates to the author that the IRE in MA Maarif Tanjung Sari teachers strongly reject all forms of radicalism that exist. A tolerant attitude must be upheld and instilled in every student.

\section{DISCUSSION ANALYSIS}

Radicalism is an understanding or sect that aims at social and political change or renewal utilizing violence or drastically. One indicator of a radical movement is the emergence of violent, brutal, and anarchist actions by certain individuals ${ }^{33}$. Radicalism has the main essence, namely the realization of the ideals of change in both social, political, and legal aspects. If we return to the definition of the term radicalism, then this sentence is rooted in radix which means tree root. Radicalism is not always viewed negatively, some religious leaders value this sentence positively if they understand it with an understanding that is following the values of Islamic teachings. Chairman of the Indonesian Mosque Council, Tarmidzi Taher commented, according to him, positive radicalism is an effort in the context of realizing tajdid (renewal) and rest (improvement), as well as a positive spirit towards positive values. So according to him, this is certainly not against Islamic law. If the word radicalism is interpreted as such, then according to Taher, Indonesia needs people with a radical spirit, to realize the civilization of the Indonesian nation which always puts forward the norms of goodness by emphasizing the concept of tajdid and islah.

In Islam, acts of anarchism, terrorism, radicalism, brutality, are actions of the Movement that were not exemplified by Rasulullah in his preaching. Islam is precisely a religion that glorifies the values of rabmatan lil alamin ${ }^{34}$, a value that prioritizes attitudes and patterns of thought and traditions of compassion among human beings. This is as said by Allah SWT: "And we did not send you, but to be a blessing for the universe" (QS. Al-Anbiya: 107). The verse clearly states how mercy and compassion are one of the greatest missions sent by the Prophets and the Apostles, especially the Prophet Muhammad. So if you find actions that are

${ }^{33}$ Asrori, "RADIKALISME DI INDONESIA: Antara Historisitas Dan Antropisitas."

${ }^{34}$ Muhamad Parhan et al., "Responding to Islamophobia by Internalizing the Value of Islam Rahmatan Lil Alamin through Using the Media," Islam Realitas: Journal of Islamic and Social Studies 6, no. 2 (2020): 139-52, http://dx.doi.org/10.30983/islam_realitas.v6i2.3695. 
not following these values, then these actions are certainly not based on the correct understanding of Islam. This is corroborated by the opinion of a contemporary scholar Yusuf al-Qadhawi. According to him, radicalism is an excessive attitude of a person religiously. There is a mismatch between creed and behavior, obligation and reality, religion and politics, speech, and action, delusion and action, the law of Allah and the product of human understanding ${ }^{35}$.

According to experts, there are at least two strong factors that are thought to be the root of radicalism birth: 1) internal factors. Partial understanding of normative arguments such as the Koran and hadith. Incomplete and imperfect understanding will trigger the birth of deviant actions that occur in society. In understanding Islam, a comprehensive approach that is carried out as a whole to a problem. According to Yusuf al-Qardhawi, the birth of radical Islamic groups such as Khawarij, Mu'tarilah, and so on was due to a wrong understanding pattern in interpreting Islam. They take verses and hadiths that they think under their political advantage and leave verses that limit the legal aspects of the previous verses and hadiths. 2) External Factors. This factor influences the development of the radical movement in Indonesia. Among them are politics, economy, power, ideology, and others. Cultural factors are also considered to have contributed significantly to the emergence of this movement. Westernization in the life of the Indonesian nation has contributed to the birth of radical movements in several regions.

Teachers are seen as the front guard in educating and guiding students to have the correct understanding and noble character. Therefore, his role and position in the world of education have a strong influence on the success of this mission. The active involvement of teachers in communicating and having dialogues with their students contributed greatly to instill the values of Islam brought by Rasulullah SAW. Islam teaches its people to have good characters such as integrity, honesty, tolerance, love for others, and other characters that contribute to the realization of a dynamic social life filled with a sense of security, peace, and prosperity.

A good teacher, of course, must be equipped with competent skills and competencies in carrying out the learning process for their students so that the knowledge transfer process can run properly and correctly. Mistakes in transferring contradictory understandings with Islamic teachings can have fatal consequences in creating radical millennial generations. Therefore, Islamic treasures, as well as a straight understanding under the majority of scholars are very crucial in forming agents of change in the nation that have an Islamic character.

The author tries to trace the efforts made by teachers to stem radicalism at Madrasah Aliyah Maarif Tanjung Sari Sumedang. To overcome radicalism in schools, Islamic Religious Education Teacher MA Maarif Tanjung Sari has a very substantial role, although at the level of implementation they are assisted by the School Leaders by involving all stakeholders. All components participate in the discourse on preventing radicalism in their schools. In addition to collaborating with the school, the Principal emphasizes the importance of intensive cooperation efforts with parents of students. Every parent has an important task, which is the same as supervising the child's development, directing, guiding, and guiding their child when they are at home or in other places. Intensive supervision and an attitude that tends not to be 2001).

${ }^{35}$ Yusuf Al-Qardhawi, At-Tatharruf Al-'Imānī Fì Muwājahati Al-Islām (Mesir Kairo: Cairo: Dar As-Syuruq, 
destructive from each parent is seen to accelerate the formation of positive mental immunity from each student so that they can filter and filter out ideas that are contrary to the views of Islamic teachings.

The main effort made by PAI teachers here is how to create a learning process that supports the creation of a straight mindset and understanding following Islamic teachings. The stages are the preparation process, implementation process, monitoring process, and evaluation process. These four processes must be considered consistently because if there is a missing process, it will have an impact on the desired output. In the preparation process, the authors see that Islamic Education teachers at this school have prepared themselves with the required knowledge before entering the learning process in the classroom. Teachers must be willing to explore the knowledge needed so that the students they teach have sufficient depth of knowledge. In addition to that, at this stage, the teacher must strive to become a qudwah (role model) for their students, so what is conveyed is in line with the actions carried out. Wrong examples and examples that don't fit what is being taught can lead to a total failure. A student's trust in his teacher will be formed when the teacher applies what he says.

Furthermore, the second process is the process of implementing learning. What kind of program is implemented at MA Maarif's school to stem radicalism? To find answers to these questions, the writer tried to interview and dig up various related information from several Islamic Religious Education teachers at MA Maarif. According to one informant source, before students carry out the learning process, all teachers are advised to carry out the procession to sing the song Indonesia Raya and Hubbul Wathan. This singing activity is seen as an effective way to cultivate the seeds of a sense of nationalism in each student so that a sense of love for the country, love for the Indonesian nation, love for a sense of unity and unity, and love for a sense of brotherhood will emerge. At least this can be a starting point in stemming radicalism among the younger generation. The author sees that this activity is not only carried out once a semester but has become a weekly routine. The author sees that this repetition process contributes to crystallizing the ideology of nationality in the minds of students because according to some educational experts, the repetition process is one of the keys to success in "humanizing" humans. As Ali ${ }^{36}$ said that repetition of behavior with learning is an action or action in the form of repeated training carried out by students to further strengthen the learning outcomes, Tambak ${ }^{37}$ also said the same thing to strengthen an association or perfect skill so that it becomes permanent.This student behavior can become a habit when habituation is carried out continuously, which becomes a character for students, of course, requires a stimulus, in behavioristic theory this requires a stimulus and students respond to $\mathrm{it}^{38}$

In the learning process, the authors conclude that there are at least five (5) principles carried out by Islamic Religious Education teachers to minimize radicalism in students. All

\footnotetext{
${ }^{36}$ Gani Ali, "Prinsip-Prinsip Pembelajaran Dan Implikasinya Terhadap Pendidik Dan Peserta Didik," AlTa'dib 6, no. 1 (2013): 31-42.

${ }^{37}$ Syahraini Tambak, "Metode Drill Dalam Pembelajaran Pendidikan Agama Islam," Al-Hikmab: Jurnal Agama Dan Ilmu Pengetahuan 13, no. 2 (2016): 110-27.

${ }^{38}$ Novi Irwan Nahar, "Penerapan Teori Belajar Behavioristik Dalam Proses Pembelajaran," NUS ANTARA: Jurnal Ilmu Pengetahuan Sosial 1, no. 1 (2016): 1-13.
} 
PAI teachers must understand and live this principle so that the process of protecting against radicalism can be carried out properly. The five principles are:

Respect for Others. The Islamic Religious Education teacher urges and emphasizes all students to always respect the rights and obligations of others so that division does not occur. Besides that, the PAI Maarif teacher also taught his students to always be able to respect the opinions of others. This is considered important to maintain harmony and brotherhood among others. Students are given the understanding that differences of opinion are natural, have become sunnatullah, cannot be avoided. This has been exemplified by the scholars, where even in the area of Fiqh (Jurisprudence), differences of opinion have become a spice in the academic discussion area. Furthermore, students are taught that respect for others is part of getting the pleasure of Allah SWT because this is certainly following the principles of da'wah taught by the Prophet Muhammad. The teacher also quoted several hadiths related to this, including the history of the hadith in which Rasulullah saw: "Not including my ummah, people who do not respect those who are older and do not love those who are younger than them and do not know the rights of knowledgeable people" (HR Ahmad.), as well as another hadith: "Every good deed is alms" (Muslim). Always striving for respect for others is a principle exemplified by the Prophet Muhammad. Muhammad Rawwās in his work describes at least 17 pedagogy principles that Rasulullah always adheres to, including being empathetic towards each individual ${ }^{39}$. A good teacher, will always recognize the characteristics of each student so that his actions and attitudes will be tailored to the personality of each person.

Moderation. The teacher instills in students to keep away from radical and extreme irrational views and actions. Religious moderation is an effort to stem radicalism and extremism. The teacher emphasizes to the students that moderation is a principle contained in the al-Qur'an. Moderation is a perspective that is not exaggerated, which is not blind fanaticism, which is neither extreme nor radical. Al-Quran in surah al-Baqarah verse 143 emphasizes that Muslims are the best (moderate) ummah among other followers. Religious moderation is deemed important to maintain a balance between life and the hereafter, spirituality with materialism, spiritual and physical. Islam does not allow its followers to carry out radical practices, even in worship ${ }^{40}$. This means that the worship carried out by a person must be following the level of his ability, not impose and exceed his capacity. Some of the companions of Rasulullah have also taken extreme actions, where some of them are committed to praying all day long regardless of their physical condition or social aspects. So this was rebuked by Rasulullah saw. Islam is precisely a religion that emphasizes the importance of balance in all things. One aspect is not allowed but other aspects are ignored ${ }^{41}$.

Respect for Creator, The teacher of Islamic Religious Education always reminds students to remember Allah SWT, be grateful for all his gifts, carry out all orders and stay away from all restrictions. All students are required to contemplate natural phenomena, why the universe

${ }^{39}$ Muhamad Rawwas, "Dirasah Tahliliyyah Li Syahshiyati Ar-Rasul Muhammad” (Lebanon Beirut: Dar AnNafais, 1988).

${ }^{40}$ Yusuf Al-Qardhawi, Kalimat Fi Al-Wasatiyyah Al-Islamiyyah Wa Ma'alimuba (Mesir Kairo: Cairo: Dar AsSyuruq, 2008).

${ }^{41} Y u s u f$ Al-Qardhawi, Fiqh Al-Wasathiyyah Al-Islämiyyah Wa At-Tajdìd Ma'älimu Wa Manārātu (Mesir Kairo: Cairo: Maktabah Wahbah, 2009). 
they see has a balance between one another. By tafakkur the signs of Allah's power through daily phenomena, it is hoped that students will be more convinced of Allah's existence which will ultimately have implications for the personality of the students. Students are of course expected to always be introspective of their deeds because Allah is always watching them at all times. The PAI teacher also emphasized the importance of actualizing Islamic religious values by strengthening the pillars of faith, namely Faith in Allah, in His angels, His Prophets and Messengers, His Book, the Day of Judgment, and His Qadha and Qadhar. One of the efforts that students must get used to maintaining relationship communication with Allah is to always tune out dhikr. According to Ali Jum'ah, a servant who always fills his daily time with dhikr to Allah, then he has the potential to open the door to ma'rifah to Allah ${ }^{43}$.

Tolerance. This is the most important thing to instill in students where cases of radicalism that arise are motivated by differences in beliefs with radical actors. An attitude of tolerance towards differences will give birth to a sense of unity and brotherhood among others. In his da'wa practice, Rosulullah saw always taught his companions to always be tolerant of differences, especially those aspects such as culture, tradition, and even faith. Islam commands its people to always preach to others for goodness, but forcing opinions, imposing ideology, imposing desires are certainly contrary to Islamic principles. The Koran emphasizes that there is no compulsion in religion (al-Baqarah: 251). This is also confirmed by the scholar Nashir Muhammad Jad in his work that one of the principles of the da'wah of Rasulullah saw, namely buriyyah al-I'tiqäd which means freedom of belief. Hidayah comes from Allah SW'T, therefore our task is only to convey, not to justify, or even impose beliefs, therefore tolerance is very important to be in forward during a multicultural and heterogeneous Indonesian society. ${ }^{44}$

Fairness. The teacher instructs students to behave fairly, avoid class favoritism and fanaticism, and respect for differences among Muslims. Islam commands its people to be fair. A mother must be fair in giving to her children. A teacher must be fair in assessing his students. Fostering a fair attitude will minimize the birth of extremism among students.

Concept Map of IRE Teacher's Efforts in Minimizing Radicalism

Figure 1. Concept Map of IRE teacher in Madrasa

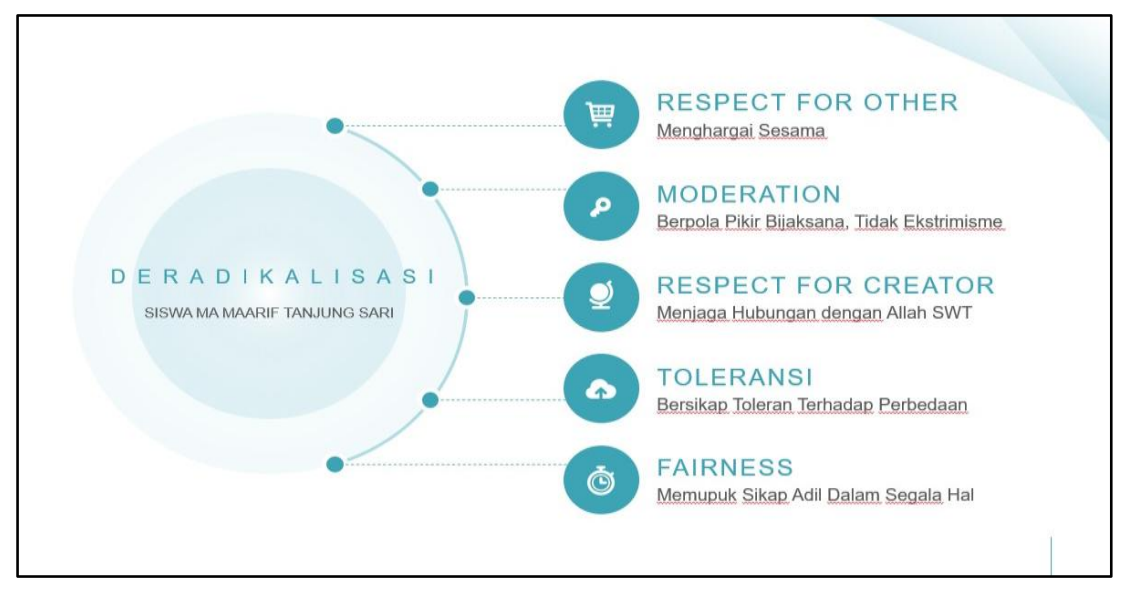

42 About contemplating, thinking, or considering seriously

${ }^{43}$ Ali Jumah, At-Thariq Ilallah (Mesir Kairo: Al-Wabil Ash-Shayyib, 2008).

${ }^{44} Y$ usuf Al-Qardhawi, Ushül Al-'Amal Al-Khairī Fì Al-Isläm Fì Dhaui An-Nushüsh Wa Al-Maqāsid As-Syarìah (Mesir Kairo: Cairo: Dar As-Syuruq, 2007). 
The third and fourth processes, namely monitoring and evaluation, involve not only the teachers at school but efforts must be made by the parents of students. The teachers advise each parent to always be actively involved in monitoring the movements of their children's daily life patterns. With consistent supervision and good communication between parents and children, the process of stemming radical understanding will quickly materialize.

Madrasa Aliyah school-age children are a community that is still psychologically vulnerable and unstable so that they are easily affected by provocations that arise in the field. The roots of radicalism in schools will very likely emerge because schools are a very potential arena. School as an arena will find its development point when there is social capital, such as an injection from agents to get a radical religious understanding itself. The main agents in the school are of course the IRE teachers at the school so that the role of the Islamic Religious Education Teacher has a strategic position to provide religious understanding to students. What the PAI teacher said would be a reference for students in worship and also in social interaction with other people.

This illustrates that the IRE MA Maarif Tanjung Sari teachers strongly reject all forms of radicalism that exist. The teachers are already literate with technological advances so that according to him, technological advances that are not accompanied by the cultivation of positive character values will cause the seeds of radicalism. According to them, MA Maarif students must be equipped with a positive mindset and mindset set. With the holding of the education process on the use of the internet, this is certainly expected to be a good start to filter out radicalism understandings that are milling about on the internet. Besides, a tolerant attitude must be upheld and instilled in every student.

\section{CONCLUSION}

Radicalism is contradiction to the teachings of Islam. Looking at its history, the radicalism movement has a very close relationship with the trends of globalization and modernization that take place at the end of the 20th century. The various views of experts on this issue have created heated debates related to the discourse of radicalism not only in Indonesia but also accross the world. The clash of ideologies between Islam and the West also facilitates the birth of new radical groups, which sometimes their ideology contradicts the Islamic religious values such as being tolerant, compassionate, and rahmatan lil alamin. The millennial generation is a generation that must be maintained. This generation has a potential to become a destructive danger if radical ideas infiltrate their mindset and they are left alone. Dynamic, integral, and comprehensive efforts from all levels of society are required in minimizing the entry of this understanding into the Indonesian state. Teachers have a very important role in protecting and protecting this millennial generation from radicalism. The intense interaction between teachers and students in the learning process at school is the main key to inserting the values of Islamic teachings that are in line with a sense of nationalism so that a millennial generation who has good morals is formed. Then what is the practical level of teacher efforts in realizing deradicalization today? The results of research conducted at MA Maarif Tanjung Sari Sumedang show that Islamic Religious Education Teachers have a strategic role in protecting their students from radicalism. The efforts made include the preparation process, the learning process, the monitoring process, and the evaluation process. The initial process is getting used 
to the tradition of singing Indonesia Raya and Hubbul Wathan songs. Also, IRE teachers also carry out the learning process by adhering to 5 main principles: respect for other, moderation, respect for creators, tolerance, and fairness.

\section{REFERENCES}

Abdallah, Abdallah. "Exclusivism and Radicalism in Schools: State Policy and Educational Politics Revisited." Studia Islamika 23, no. 3 (December 30, 2016): 625-32. https://doi.org/10.15408/sdi.v23i3.4425.

Ali, Gani. "Prinsip-Prinsip Pembelajaran Dan Implikasinya Terhadap Pendidik Dan Peserta Didik." Al-Ta'dib 6, no. 1 (2013): 31-42.

Ali, Zahra. "Being a Young British Iraqi Shii in London: Exploring Diasporic Cultural and Religious Identities between Britain and Iraq." Contemporary Islam 13, no. 3 (2019): 349-67. https://doi.org/10.1007/s11562-018-0433-y.

Al-Qardhawi, Yusuf. At-Tatharruf Al-'Imānì Fì Muwājahati Al-Isläm. Mesir Kairo: Cairo: Dar As-Syuruq, 2001.

—. Drāhiratu Al-Gulunwu Fì At-Takefir. Mesir Kairo: Cairo: Maktabah Wahbah, 1990.

—. Fiqh Al-Wasathiyyah Al-Islämiyyah Wa At-Tajdìd Ma'älimu Wa Manārātu. Mesir Kairo: Cairo: Maktabah Wahbah, 2009.

- Kalimat Fi Al-Wasatiyyah Al-Islamiyyah Wa Ma'alimuba. Mesir Kairo: Cairo: Dar AsSyuruq, 2008.

-.Ushūl Al-'Amal Al-Khairī Fì Al-Isläm Fì Dhaui An-Nushūsh Wa Al-Maqāsid As-Syarìah. Mesir Kairo: Cairo: Dar As-Syuruq, 2007.

Arifianto, Alexander R. "Islamic Campus Preaching Organizations in Indonesia: Promoters of Moderation or Radicalism?" Asian Security 15, no. 3 (September 2, 2019): 323-42. https://doi.org/10.1080/14799855.2018.1461086.

Arifin, Syamsul. "Islamic Religious Education and Radicalism in Indonesia: Strategy of deRadicalization through Strengthening the Living Values Education." Indonesian Journal of Islam and Muslim Societies 6, no. 1 (2016): 93-126. https://doi.org/10.18326/ijims.v6i1.93-126.

Asrori, Achmad. "Contemporary Religious Education Model on the Challenge of Indonesian Multiculturalism." JOURNAL OF INDONESIAN ISLAM 10, no. 2 (December 1, 2016): 261-84. https://doi.org/10.15642/JIIS.2016.10.2.261-284.

Asrori, Ahmad. "Radikalisme Di Indonesia: Antara Historisitas Dan Antropisitas." KALAM 9, no. 2 (December 30, 2015): 253-68. https://doi.org/10.24042/klm.v9i2.331.

- "RADIKALISME DI INDONESIA: Antara Historisitas Dan Antropisitas." Kalam 9, no. 2 (2017): 253. https://doi.org/10.24042/klm.v9i2.331.

Azca, Muhammad Najib, Hakimul Ikhwan, and Moh Zaki Arrobi. "A Tale of Two Royal Cities: The Narratives of Islamists' Intolerance in Yogyakarta and Solo." Al-Jami'ah 57, no. 1 (2019): 25-50. https://doi.org/10.14421/ajis.2019.571.25-50.

Baidhawy, Zakiyuddin. "The Muhammadiyah's Promotion of Moderation." American Journal of Islamic Social Sciences 32, no. 3 (2015): 69-91.

Briggs, R., C. Fieschi, and H. Lownsbrough. "Bringing It Home: Community-Based Approaches to Counter-Terrorism." DEMOS, 2006.

Burke, J. “Al-Qaeda: The True Story of Radical Islam.” Penguin, 2004.

Choudhury, T. "The Role of Muslim Identity Politics in Radicalisation (a Study in Progress)." Department for Communities and Local Government, 2007.

Davids, Nuraan. "Islam, Moderation, Radicalism, and Justly Balanced Communities." Journal of Muslim Minority Affairs 37, no. 3 (July 3, 2017): 309-20. https://doi.org/10.1080/13602004.2017.1384672. 
Fadlan, Muhammad Nida', and Rangga Eka Saputra. "Islam, Radicalism, Democracy, and Global Trends in Southeast Asia." Studia Islamika 24, no. 3 (2017): 643-47. https://doi.org/10.15408/sdi.v24i3.6566.

Fanani, Ahmad Fuad. "The Global War on Terror, American Foreign Policy, and Its Impact on Islam and Muslim Societies." Indonesian Journal of Islam and Muslim Societies 1, no. 2 (2011): 205-27. https://doi.org/10.18326/ijims.v1i2.205-255.

Glees, A., and C. Pope. "When Students Turn to Terror: Terrorist and Extremist Activity on British Campuses." Social Affairs Unit, 2005.

Haryani, Tiyas Nur, Muhammad Ikhsanul Amin, Nur Hidayatul Arifah, and Arina Mardhiyana Husna. "Islamic Education in Supporting De-Radicalization: A Review of Islamic Education in Pondok Pesantren." Nadwa 12, no. 2 (January 7, 2019): 259-72. https://doi.org/10.21580/nw.2018.12.2.2581.

Jahroni, Jajang. "Modernisme Dan Radikalisme Islam Di Indonesia: Menafsirkan Warisan Muhammad 'Abduh Dan Rashīd Rị̣ā." Studia Islamika, 2004. https://doi.org/10.15408/sdi.v11i3.599.

Jumah, Ali. At-Thariq Ilallah. Mesir Kairo: Al-Wabil Ash-Shayyib, 2008.

Kartiko, Ari, Muhammad Mujtaba Mitra Zuana, Akhmad Sirojuddin, Muhammad Huusnur Rofiq, and Muhammad Anas Maarif. "Aswaja Ke-Nuan-Based Islamic Moderate Education as a Radicalism Strategy." Al-Afkar, Journal For Islamic Studies 3, no. 2 (October 8, 2020): 88-101. https://doi.org/10.31943/afkar_journal.v3i2.98.

Kepel, G. "Jihad: The Trial of Political Islam." Harvard University Press, 2002.

Khozin, Wahid. "Sikap Keagamaan Dan Potensi Radikalisme Agama Mahasiswa Perguruan Tinggi Agama." EDUKASI: Jurnal Penelitian Pendidikan Agama dan Keagamaan 11, no. 3 (December 1, 2013). https://doi.org/10.32729/edukasi.v11i3.415.

Kühle, Lene. "Policies of Radicalisation as Anti- A Nd Countercult Ideologies." Journal of Muslims in Europe 7, no. 2 (June 2018): 211-36. https://doi.org/10.1163/2211795412341367.

Mahfud, Choirul, Niken Prasetyawati, Wahyuddin Wahyuddin, Zainul Muhibbin, Dyah Satya Yoga Agustin, and Heni Sukmawati. "Religious Radicalism, Global Terrorism and Islamic Challenges in Contemporary Indonesia." Jumal Sosial Humaniora 11, no. 1 (July 27, 2018): 8-18-18. https://doi.org/10.12962/j24433527.v11i1.3550.

Marzuki, Marzuki, Miftahuddin Miftahuddin, and Mukhamad Murdiono. "Multicultural Education in Salaf Pesantren and Prevention of Religious Radicalism in Indonesia." Jurnal Cakrawala Pendidikan 39, no. 1 (February 2, 2020): 12-25. https://doi.org/10.21831/cp.v39i1.22900.

Muzakki, Akh. "Islamic Radicalism in Southeast Asia: With Special Reference to the Alleged Terrorist Organization, Jamā'ah Islāmiyah." Al-Jami'ab: Journal of Islamic Studies 42, no. 1 (2008): 61-87. https://doi.org/10.14421/ajis.2004.421.61-87.

Nahar, Novi Irwan. "Penerapan Teori Belajar Behavioristik Dalam Proses Pembelajaran." NUS ANTARA: Jurnal Ilmu Pengetahuan Sosial 1, no. 1 (2016): 1-13.

Parhan, Muhamad, Mohammad Rindu Fajar Islamy, Nurti Budiyanti, Risris Hari Nugraha, and Pandu Hyangsewu. "Responding to Islamophobia by Internalizing the Value of Islam Rahmatan Lil Alamin through Using the Media." Islam Realitas: Journal of Islamic and Social Studies 6, no. 2 (2020): http://dx.doi.org/10.30983/islam_realitas.v6i2.3695.

Ragazzi, Francesco. "Du Ceri," n.d.

Rawwas, Muhamad. "Dirasah Tahliliyyah Li Syahshiyati Ar-Rasul Muhammad." Lebanon Beirut: Dar An-Nafais, 1988. 
Sholeh, Badrus. "Conflict, Jihad, and Religious Identity in Maluku, Eastern Indonesia." AlJamiah: Journal of Islamic Studies 46, no. 1 (2008): 71-99. https://doi.org/10.14421/ajis.2008.461.71-99.

Sing, Manfred. "Brothers in Arms: How Palestinian Maoists Turned Jihadists." Welt Des Islams. Brill, February 2011. https://doi.org/10.1163/157006011X556111.

Tambak, Syahraini. "Metode Drill Dalam Pembelajaran Pendidikan Agama Islam." AlHikmah: Jurnal Agama Dan Ilmu Pengetahuan 13, no. 2 (2016): 110-27.

Umar, Muhammad Sani, and Mark Woodward. "The Izala Effect: Unintended Consequences of Salafi Radicalism in Indonesia and Nigeria." Contemporary Islam 14, no. 1 (April 2020): 49-73. https://doi.org/10.1007/s11562-019-00441-y.

Weismann, Itzchak. "A Perverted Balance: Modern Salafism between Reform and Jihād* ." Die Welt Des Islams 57, no. 1 (March 2017): 33-66. https://doi.org/10.1163/15700607$00571 \mathrm{p} 04$.

Yunus, A Faiz. "Radikalisme, Liberalisme Dan Terorisme: Pengaruhnya Terhadap Agama Islam." Jurnal Online Studi Al-Qur An 13, no. 1 (2017): 76-94. https://doi.org/10.21009/jsq.013.1.06. 